\title{
Burden of uterine fibroids in Italy: epidemiology, treatment outcomes, and consumption of health care resources in more than 5,000 women [Corrigendum]
}

\author{
Chiumente M, De Rosa M, Messori A, Proli EM, ClinicoEco- \\ nomics and Outcomes Research. 2017;9:525-535
}

On page 529, Ancillary study section, the 3rd sentence "Patients had a mean age of 45 years; Charlson index was about $1 \%$ and $10.9 \%$ after medical therapy underwent surgery" should have read "Patients had a mean age of 45 years and the Charlson index was about $1 \%$; after medical therapy 148 patients (10.9\%) underwent surgery".

\section{Publish your work in this journal}

ClinicoEconomics and Outcomes Research is an international, peerreviewed open-access journal focusing on health technology assessment, pharmacoeconomics and outcomes research in the areas of diagnosis, medical devices, and clinical, surgical and pharmacological intervention. The economic impact of health policy and health systems organization also constitute important areas of coverage. The manuscript management system is completely online and includes a very quick and fair peer-review system, which is all easy to use. Visit http://www.dovepress.com/testimonials.php to read real quotes from published authors.

Submit your manuscript here: https://www.dovepress.com/clinicoeconomics-and-outcomes-research-journal 